\title{
The Scientific Collaboration Networks in University Management in Brazil
}

\section{Liária Nunes Da Silva ${ }^{1,2}$, Alan Malacarne¹, José Walter Silva e Silva², Flávio Valdir Kirst², Robelius De-Bortoli1}

\author{
${ }^{1}$ Federal University of Sergipe, Aracaju, Brazil \\ ${ }^{2}$ Federal Institute of Education and Technology of Piauí, São João do Piauí, Brazil \\ ${ }^{3}$ Doctum College, Serra, Brazil \\ Email: liaria.nunes@ifpi.edu.br, alanmalacarne1988@gmail.com, waltersilva@ifpi.edu.br, flaviokirst@yahoo.com.br, \\ robelius@yahoo.com.br
}

How to cite this paper: Da Silva, L. N., Malacarne, A., e Silva, J. W. S., Kirst, F. V., \& De-Bortoli, R. (2018). The Scientific Collaboration Networks in University Management in Brazil. Creative Education, 9, 1469-1483.

https://doi.org/10.4236/ce.2018.99109

Received: May 28, 2018

Accepted: July 28, 2018

Published: July 31, 2018

Copyright () 2018 by authors and Scientific Research Publishing Inc. This work is licensed under the Creative Commons Attribution International License (CC BY 4.0).

http://creativecommons.org/licenses/by/4.0/

\begin{abstract}
The scientific collaboration, externalized through the formation of networks or research groups, has been used by researchers in the processes of production and publication of researches in the various areas of knowledge. On the basis of this, the aim of this article is to identify the structure of scientific collaboration networks in University Management among higher education institutions, based on the institutional links of researchers in this area. In terms of methodological steps, two data collections were done: one in the publications database of the Journal of University Management in Latin America (GUAL) to select the articles of interest in the research, and another in the current database of the Directory of Research Groups (DRG) of the National Council for Scientific and Technological Development (CNPq) to identify the research groups in University Management registered in the Directory. The main results evidenced the predominance of scientific collaboration in the production of research in the area and that the formation of networks is influenced by several factors, such as social aspects and professional aspirations of researchers, interests in sharing resources, as well as the geographical proximity of institutions.
\end{abstract}

\section{Keywords}

Research Groups, Scientific Production, Higher Education Institutions, Networking, $\mathrm{CNPq}$

\section{Introduction}

The scientific collaboration, characterized as the interaction between two or 
more scientists in the development of researches, sharing experiences, physical structures, beyond intellectual and economic resources (Campos et al., 2017), has been used by Higher Education Institutions and Research Institutions as an effective means to connect researchers and promote the enjoyment of experiences and knowledge, as well as providing opportunities for research production and publications in qualified and high impact factor journals. In Brazil, the stimuli for the formation of groups of research in the different areas of knowledge are related to the policies of Science, Technology and Innovation (CT \& I) (Leite et al., 2014; Santana et al., 2014).

The institutionalization of the Brazilian policy of "CT \& I" occurred in 1951 with the National Council for Scientific and Technological Development (CNPq), created to foster scientific research, the technological development and encourage the personnel training. It was meant to develop an internal technological capacity to meeting the demands of the industrial sectors for technologies, given the space that the technological development achieved in the guidelines of the country's strategic policy, began to be discussed as necessary for the modern developmental state to reach its objectives (Oliveira, 2016).

Although it was conceived as an agency that fosters the country's scientific research, $\mathrm{CNPq}$ never presented an institutional shield that would make it resistant to the changes in the national historical-political contexts or to the understanding of the role of scientific and technological research in the development of Brazil (Domingos, 2004).

The national scenario of scientific production is transformed from the year 2000 with the new measures adopted in the field of science and technology policies. It is in this period, that the National System of Science and Technology goes to a process of changes with actions directed to encouragement of research, through a series of financial, political and institutional strategies, but also focused on mitigating the state's obligations in the financing research and the production of knowledge. The creation and regulation of sectoral funds and the Center for Management and Strategic Studies (CGEE), as well as stimulating the formation of collaborative research networks, were the main actions of the reform, which further reduced CNPq's participation in the formulation of the country's science and technology policies, as well as its competence to grant scholarships and incentives to researchers (Guimarães, 2002).

However, it is from 2003 that scientific production has increased significantly, a year in which the $\mathrm{CNPq}$ stabilizes administratively and financially, starting to resume its capacity to act in the promotion of the country's science and technology policies. A series of actions directed to the promotion of knowledge production and the new scenario of the National System of Science and Technology, such as the increase in the amount of resources destined to the granting of scholarships, the constant publication of research calls for papers, a varied source of funds for financing, the institutionalization of other forms of subsidy and the consolidation of state research agencies (Domingos, 2004). 
Although CNPq reacquired the protagonist of Brasil's science and technology policies only from 2003, it is important to highlight the creation of the Directory of Research Groups (DRG) in the 1990s, a period of great structural and financial Advice.

In order to collect information on research groups in Brazilian teaching and research institutions, as well as to make them available to interested parties in general, DRG/CNPq presents data about researchers, institutions, research lines, knowledge, application sectors involved, scientific, technological and artistic production, as well as partnerships between groups and institutions-key information for the evaluation, monitoring and targeting of research incentive policies (CNPq, 2018).

The results of the last census carried out by the DRGin 2016 indicated 37,640 different research groups certified by 531 institutions, a growth of $6 \%$ compared to 2014. Compared to the percentage identified in 2002-year in which the form (CNPq, 2016), confirming the patent predisposition of the researchers to promote scientific collaboration, from the organization of Groups around specific lines of research and knowledge sharing and infrastructure, observed by Santana et al. (2014).

Promoted since the process of changes that the National System of Science and Technology underwent since the year 2000, research collaboration networks have been the subject of study by researchers from the different areas of knowledge. The studies on this theme seek, among other objectives, to map and analyze the networks of scientific collaboration of the areas, identifying the structure of relationship between institutions or researchers. Soares, Souza and Moura (2010), for example, demonstrated the tendency of scientific collaboration in the production of research in the areas of Political Science and Sociology. Cruz et al. (2011) outlined the profile of the collaboration networks formed among the researchers involved in the Congress of Accounting and Accounting of the University of São Paulo (USP). Already Çavuşoğlu and Türker (2014) have developed networks of scientific collaboration in the fields of engineering, mathematics, physics and medicine as a subset of the Turkish collaboration network.

In the area of University Management, a great part of the researches are also being developed by collaboration networks, formed from the connection between researchers affiliated to Higher Education Institutions and Research Institutions distributed by Brazil, presenting similar behavior to that verified by Leite et al. (2014) when they affirm that networks are based on the connections that form among a group of people, institutions, agencies or companies, aiming together to develop research and the progress of science.

In the development of research realized in the context of University Management, it is possible to obtain solutions applicable to several managerial problems faced by Higher Education Institutions, such as the use of tools to support strategic management (Pucciarelli \& Kaplan, 2016), the implementation of effective management processes to assist managers in decision-making in the face of environmental uncertainties (Jacamossi \& Silva, 2016); the impact of developing 
organizational learning and creativity on innovation and service delivery efficiency (Sutanto, 2017), or even the importance of senior management's commitment to the adoption and implementation of the PRME (Principles for Responsible Management Education) - an initiative of the United Nations that has the objective to establish a process of continuous improvement of business schools worldwide (Wersun, 2017).

Considering the importance given to University Management in Brazil, perceived from the Graduate Programs, Research Institutes, Periodicals specialized in the field and the expressiveness of collaboration networks in research in the scientific development of the various areas of knowledge, this article has the objective to identify the structure of the networks of scientific collaboration in University Management among the Institutions of Higher Education, based on the institutional links of the researchers of the area.

\section{Methodology}

The identification of the structure of scientific collaboration networks in University Management, in this research, is based on information collected in two data bases: the publication database of the University Management Journal in Latin America (GUAL) - the selection of this journal for the selection of papers is related to its coverage, focus and scope and the current basis of the CNPq Research Groups Directory (DRG)-because, from it, it is possible to identify the set of researchers and research groups to which they belong.

The GUAL Magazine is linked to the Institute of Research and Studies in University Administration of the Federal University of Santa Catarina (INPEAU/UFSC) and aims to stimulate research and debate on issues related to University Management and Higher Education in Latin America and publishes four annual editions, with fifteen articles each, totaling an amount of sixty articles per year. The scientific production available in the journal's database is the result of the studies of Brazilian researchers and other Latin American countries and addresses several topics with a focus on the managerial aspects of Higher Education Institutions. Its publications are directed to managers of higher education institutions, researchers, teachers and students are indexed in the Network of Scientific Journals of Latin America and the Caribbean, Spain and Portugal (REDALYC); Regional Online Information System for Scientific Journals of Latin America, the Caribbean, Spain and Portugal (LATINDEX); Directory of Open Access Journals (DOAJ); and Portal of Journals of the Federal University of Santa Catarina (GUAL, 2018).

The selection criteria of the articles will obey a temporal cut of five years, collecting, therefore, articles published between the years of 2012 and the first half of 2017, whether in the Portuguese language or in the Spanish language. We selected publications that dealt with subjects related to the management of Higher Education Institutions and which presented in the title, abstract or keywords, the following expressions: University Management; Management of Higher Education Institutions; Strategy; Strategic management; Strategic planning; Manage- 
ment model; Institutional Development Plan and Competitive Advantage. The objective of this stage was to identify if the scientific production in this journal is being developed in coautorship or single authorship, as well as to understand the interactions between the Institutions of Higher Education, from the connections between the several researchers.

Once the information was collected in the GUAL Magazine, a search was made on the current basis of the DRG/CNPq, on April 20, 2018, to identify the research groups in University Management. In addition to using the term University Management as the search term in the "Group Name" and "Search Line Name" fields, two filters were applied at that time: the first one in the Knowledge Area-the predominant Large Area of the selected group was "Applied Social Sciences" and the second filter in the predominant area of the group-where the "Administration" option was made. In order to better characterize the research groups in University Management, the narrated procedures were repeated, now filtering the predominant Area of the group from the option "Human Sciences" and the predominant Area of the group with the option "Education"-for the results obtained in both filters, the elements highlighted for analysis were the institution of the group, the lines of research and the names of the researchers. The purpose of this search was to identify the institutions that make up the collaborative network that have groups or lines of research on the subject, in addition to realizing if the researchers of such groups participated in the collaborative network. For this, the data of the groups identified with the information obtained from the publication database of the GUAL Magazine were compared, comparing the names of the researchers linked to the groups with the authors of the selected articles.

Cytoscape, an open-source software platform for visualization of complex networks, data integration and analysis (http://www.cytoscape.org/) was used to make the graphs. And even it was developed specially to be used in the modeling and visualization of biological networks, the software packageCytoscape has been successfully used by researchers from other areas (Killcoyne et al., 2009; Smoot et al., 2011).

\section{Results and Discussion}

Analyzing the authorship of the 73 articles identified from the applied methodology, it was observed that 245 authors and coauthors, affiliated to 63 different Higher Education Institutions, were responsible for this volume of production and that only 18 of them were involved in the production of more of an article.

Of the 73 articles selected, 68 (93.15\%) were produced in coauthories and only $05(6.85 \%)$ were developed by single authors, revealing the predominance of scientific collaboration in the area (Figure 1) and confirming the researches carried out by Adams (2012), which identified a worldwide trend in collaboration networks.

Understanding that collaboration networks represent the links between researchers and institutions regarding scientific production (Silva et al., 2012), 


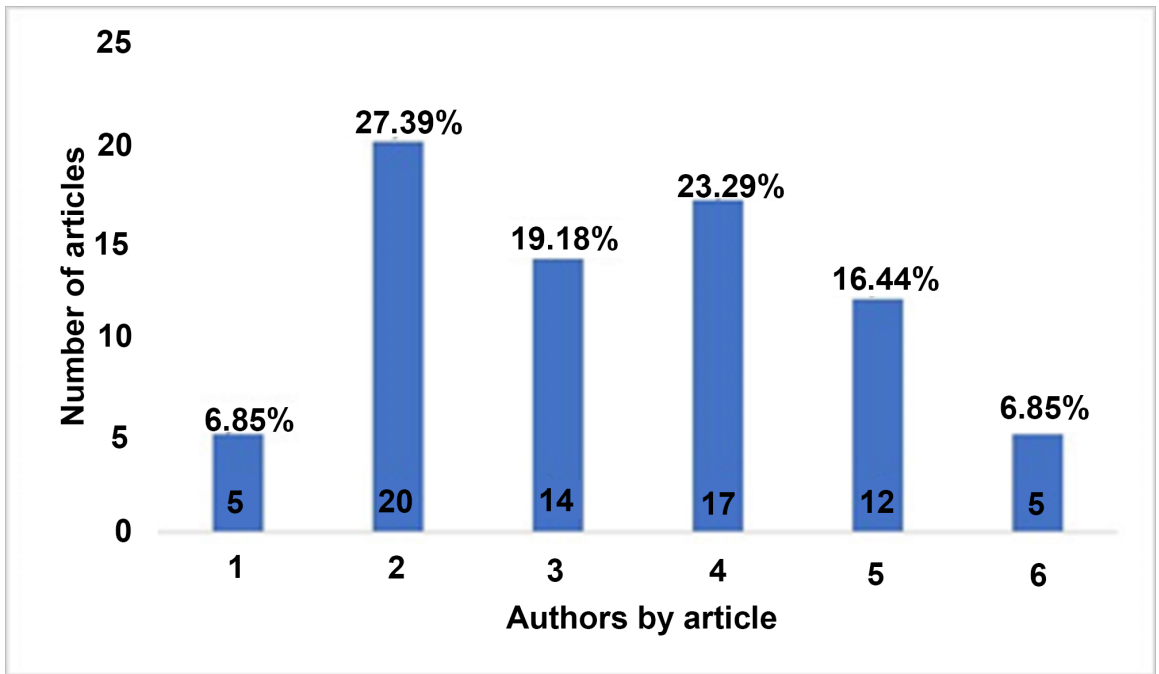

Figure 1. Number of authors per article.

Figure 2 presents collaboration networks in University Management, demonstrated by the relationships between the 63 Institutions identified. They were obtained based on the institutional affiliations of the 245 authors and co-authors, based on the analysis of the 73 articles selected. The presented graphs were constructed with the following characteristics: the articles are represented by the standard, year/article (example 2012/1), the Institutions of Higher Education are identified by their respective acronyms, and the interactions between the Institutions are evidenced from the link (each link represents the institutional link of an author and co-author who participated in the elaboration of the article).

Two realities can be observed from Figure 2. The first one refers to the presence of a main component within the network, through which the sharing of information, intellectual resources or infrastructure is more dynamic, in contrast to the several smaller components formed, sometimes by isolated institutions, or by groups of up to four Higher Education Institutions. It is the contrast of these realities, expressed by the different volumes of scientific production in collaboration of the researchers who belong to them, who, in and of itself, indicated for the fragmentation of the network.

There are several factors that may have contributed to the construction of the two realities highlighted in Figure 2, which can be found in the literature produced on the subject. Vanz and Stump (2010), for example, have identified seventeen reasons that may favor scientific collaboration networks, such as the researcher's intention to raise his/her scientific popularity and productivity index; the formation of working groups based on personal relationships; obtaining and/or expanding financing, resources, special equipment, materials; rationalization of the use of the scientific labor force and time spent on research, or even the training of researchers and counselors, and the possibility of greater dissemination of research, among others. In addition to these reasons, the geographical distance between institutions, and consequently among Brazilian researchers, 


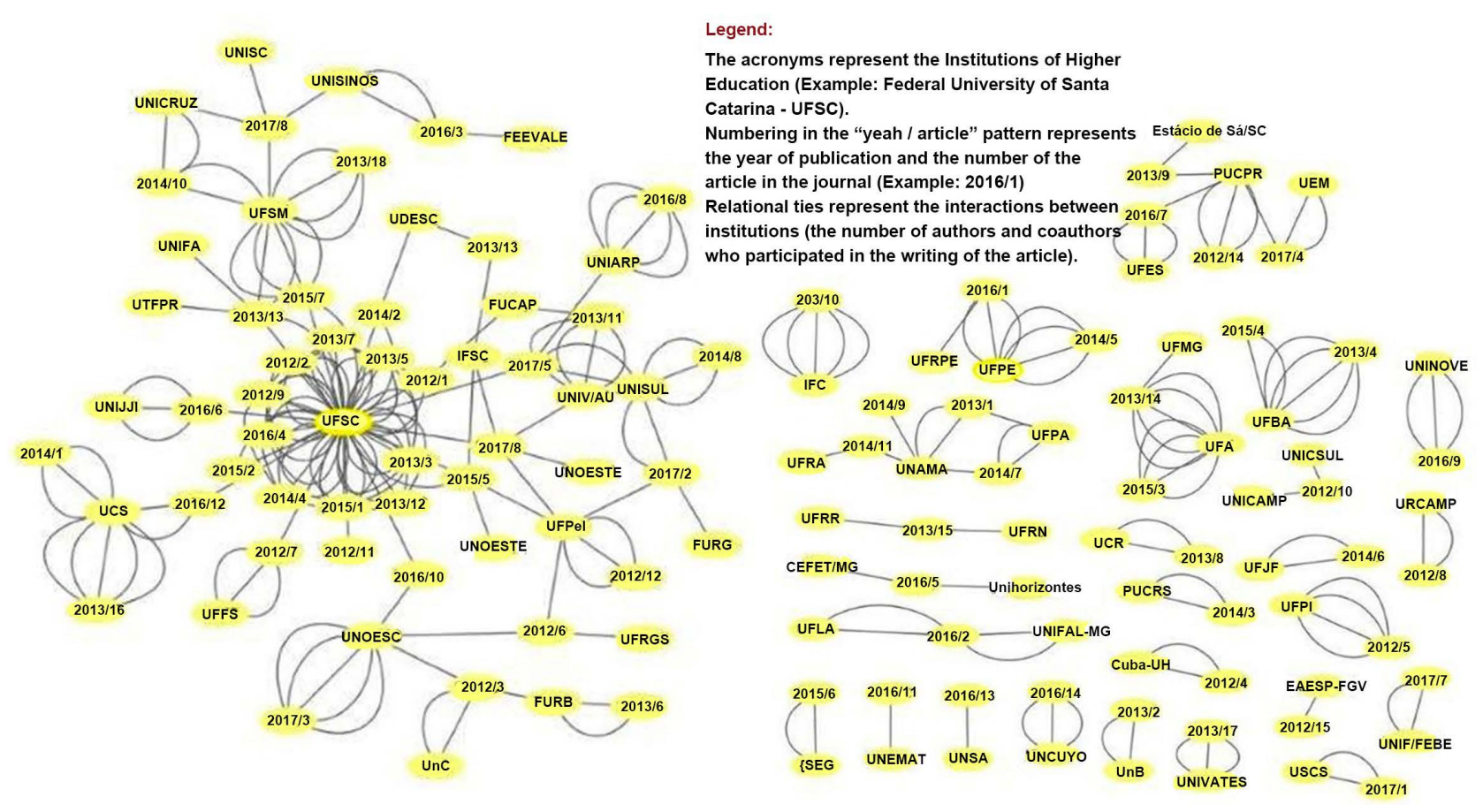

Figure 2. Network of scientific collaboration between Institutions of Higher Education in University Management in the period 2012 to 2017. 


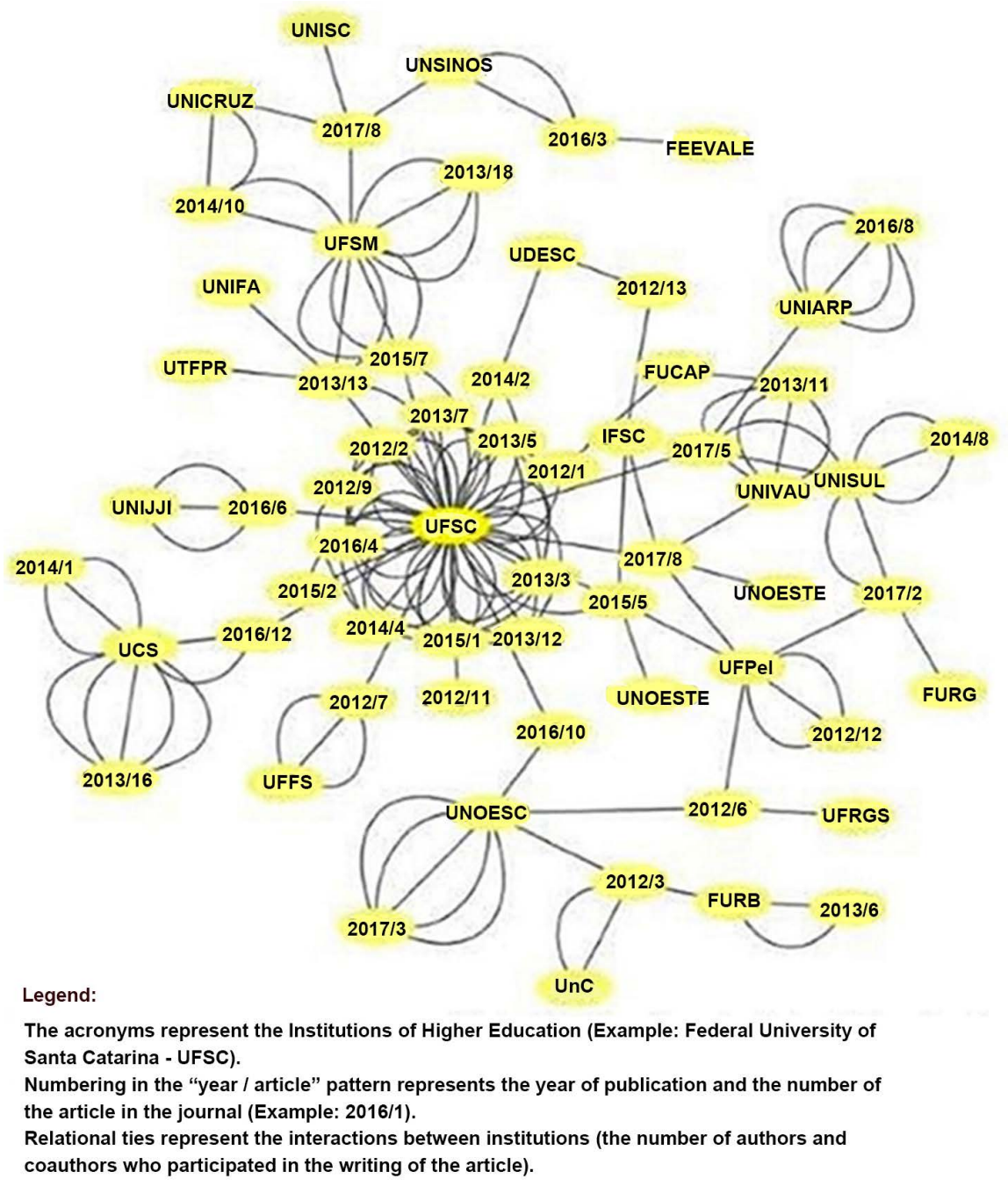

Figure 3. Collaboration network between Institutions of Higher Education in University Management in the period 2012 to 2017 (Principal component).

component is related to the geographical proximity that these institutions are of the Federal University of Santa Catarina (UFSC), the central institution of the main component, presenting the greatest amount of relational links with the other institutions, being also the most prolific of the network, since of the 73 articles selected, the institution collaborated with 21 (28.76\%).

Analyzing articles selected from intra-bias and collaborative interinstitutionality, it was observed that $52.05 \%$ ( 38 articles) were produced in collaboration with the institutions that make up the main component of the network (Figure 3). Of this universe, $44.73 \%$ presented an intrainstitutional collaborative character, $52.63 \%$ interinstitutional, and only $2.63 \%$ of the articles were produced by single authorship. These percentages show that the structuring dynamics of this component of the collaboration network in University Management are influenced by the social factors of the researchers, such as the institutional link, thematic affinity and personal relations, geographical proximity or interest in the sharing of physical and intellectual resources, as already indicated. 


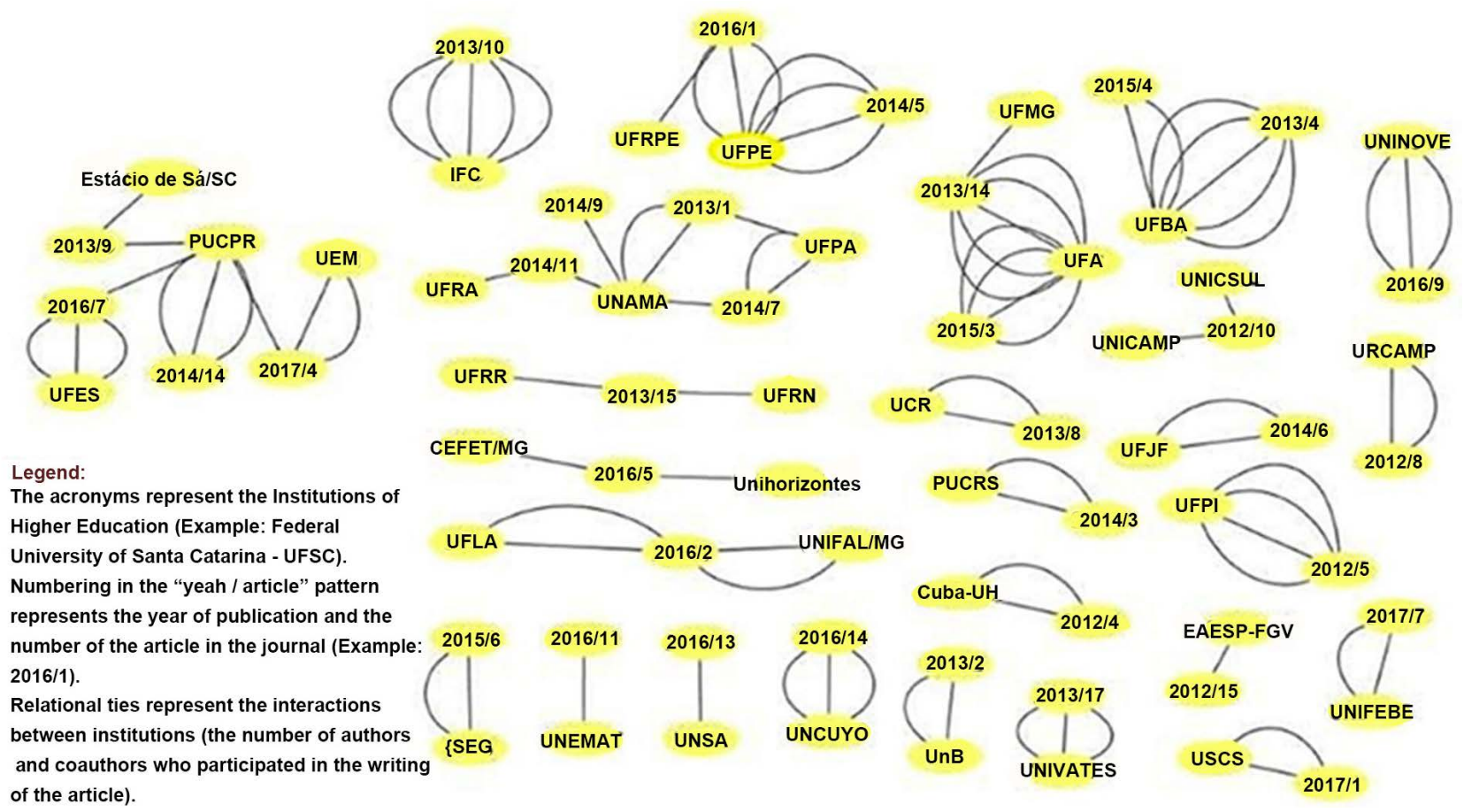

Figure 4. Network of collaboration between Institutions of Higher Education in University Management in the period 2012 to 2017 (Smaller components).

Furthermore, the geographical aspects, the institutional aspects also influence the formation of research clusters (Santin, Vanz, \& Stumpf, 2016), as an example of post-graduate programs, which are the origin of the production of new knowledge, through the systematic and permanent construction of research (Severino, 2009). The emphasis of Southern Higher Education institutions on the composition of the collaborative network, especially of the UFSC (Figure 3) is directly related to the scientific production promoted by the researchers of the postgraduate program in University Management and the Research and Studies in University Administration (INPEAU), both hosted by the institution.

In addition, it should be pointed out that the active participation of UFSC in this network of scientific collaboration, based on the publication database of GUAL Magazine, points to evidence of endogeny in the journal, a phenomenon that occurs, according to Valerio (1994), when the main authorship holder and scientific production of a particular journal is the publishing institution itself.

Concerning to the smaller components, with respect to the geographic aspect it is possible to perceive a spatial diversity, significantly, more broadly, even with the presence of international institutions. While in the main component the Southeast and South Regions predominated exclusively, in the smaller components these regions, although they presented the highest percentages of collaboration, respectively $37.84 \%$ and $18.92 \%$, shared space with international institutions (13,51\%) and all regions of the country (Northeast: $13.51 \%$, North: $10.81 \%$, Midwest: 5.40\%) (Figure 4).

With regard to the dynamics of the scientific collaboration of the institutions 
that make up the smaller components of the network, it was observed that of the 35 articles produced (47.94\% of the total articles selected), $54.28 \%$ were elaborated in intrainstitutional collaboration, $34.28 \%$ in interinstitutionality collaboration and $11.42 \%$ represented the sole authors (Figure 4).

Although the volume of scientific production of smaller components, 35 articles, present similarity to the main component, 38 articles, it was noticed that the interinstitutional collaboration in the smaller components of the network is more limited when compared to the connections of the main component, whereas the articles produced in intrainstitutional collaboration and in single authorship have higher percentages.

Of the 37 institutions that make up the minor components 18 (48.64\%) are isolated within the network, that is, they did not contribute any other institution to the production of research, a percentage that shows even more that the field of research in University Management is relatively fragmented (Figure 4). However, it should be noted that this is not a peculiarity of the University Management area. Rossoni, Hocayen-da-Silva and Ferreira Júnior (2008) carried out a study on the relationship structure between research institutions in the field of science and technology in Brazil and identified that of the 232 research institutions 54 were isolated (23\%).

After the identification of the collaborative network, we sought to verify the institutions that have research groups or lines of research in University Management regularly registered in the $\mathrm{DRG} / \mathrm{CNPq}$, as well as to identify themselves. There was the participation of the researchers of these groups in the collaborative network.

The search for Research Groups in University Management by the predominant Area "Administration" resulted in five groups, linked to four Higher Education Institutions: three of these groups are hosted by the Federal Frontier University (UFFS), Federal University of Espírito Santo (UFES) and the Fluminense Federal University (UFF) and two from the Federal University of Santa Catarina (UFSC). The number of research lines varies between two and five, with a registered average of three research lines per group.

If there is a relative uniformity in the dispersion of the number of Research Lines found by Groups, the same cannot be said in relation to the number of researchers. The analysis of the collaboration of the researchers of these groups pointed to two extremes: while three of the five groups did not present any researchers in the collaborative network formed from the articles selected in the GUAL Magazine during the period studied, the UFFS group collaborated with the network from the scientific production of three researchers and one of the UFSC groups collaborated through the researches of twenty-three authors. The more intense collaboration of the UFSC Research Group explains the more active participation of the university in the network, as well as the signs of endogeny in the GUAL Magazine, pointed out from the analysis of Figure 3.

When the Research Groups were filtered by the predominant area "Education" returned three groups. As it happened in the groups of the Administration 
area, the research groups in the Education area also presented a similar behavior in relation to the number of lines of research. With the exception of the group of the State University Paulista Júlio de Mesquita Filho (UNESP) that has four lines of research, the groups of the University of Vale do Rio dos Sinos (UNISINOS) and the Faculty CESUSC (CESUSC) each have two lines of researches. Curious is to realize that none of the researchers that make up these groups contributed to the collaborative network formed from the GUAL Magazine during the period studied.

Another observation was related to the participation of UNISINOS in the main component (Figure 3) and UFES in the smaller components of the collaborative network (Figure 4), which occurred not through the scientific collaboration of the researchers linked to the groups identified in the DRG/CNPq which has as one of its lines of research the University Management, but from the participation of other researchers of the institution.

Moreover, it was noticed that of the total number of authors and co-authors (245) responsible for the production of the 73 articles selected, only $10.61 \%$ are linked to research groups that have university management as a research line. This means that much of the scientific collaboration in the field has been developed by informal groups of researchers and not exclusively from groups of formally created and certified research. Characteristics observed by Vanz and Stump (2010) when they carried out a theoretical-conceptual review on collaboration scientific basis. For the authors are the informal relations between the researchers that give rise to a great part of the collaborations in research.

This observation also finds symmetry in the conclusions pointed out in the studies of Solla Price and Beaver (1966) and Solla Price (1976). According to the authors, scientific collaboration occurs through invisible colleges, in other words, informal communities of researchers are often formed from meetings at scientific events and institutional visits. These meetings favor the formation of informal groups of works through the thematic affinity of the researchers, the interest in sharing physical, financial and intellectual resources, as well as the geographic proximity of the institutions.

\section{Final Considerations}

In Brazil, scientific collaboration takes place within the framework of invisible colleges, from the informal networks of researchers, as well as within the research groups formally created and registered in the DRG/CNPq. In the present work, the structure of the network of scientific collaboration in University Management among Higher Education Institutions was demonstrated, from the institutional links of researchers in the area.

Studies on research collaboration networks highlight several aspects of a field of knowledge, including the processes of scientific production. Collaboration networks in University Management revealed the dynamics of knowledge production, the most prolific and connected institutions within the network, as well 
as isolated institutions. This information is configured as a strategic management tool so that institutions not only evaluate their participation, but also define strategies to strengthen their own network from new partnerships.

It was verified that a great part of the scientific production in University Management has been developed in scientific collaboration between researchers linked to institutions of the different regions of Brazil, but also evidenced the regional and local clusters of these surveys, formed in function of social aspects and professional aspirations of researchers, interests in sharing resources, and geographical proximity.

In the face of the number of Higher Education Institutions and the need for academic production aimed at the management of these complex institutions, it was noticed that the University Management area still has space for the emergence of new groups and lines of research, since the quantity of groups found in the $\mathrm{DRG} / \mathrm{CNPq}$ is still modest compared to the results from other areas. Although the University Management in Brazil is already being approached by the graduate programs and its scientific production elaborated from the collaboration networks or the single authorship, it is necessary to stimulate the connection between the institutions of the different regions of the country, to the network to achieve greater regional and national visibility. As a strategy for strengthening the network, it is suggested to encourage the creation and institutional strengthening of scientific collaboration through research groups.

Considering that the scientific production of the area represents a source of research for managers of Higher Education Institutions and others interested in the subject, the network can be perceived even as a strategic map, pointing out the main knowledge production centers and their diverse connections. This information will guide the search for papers that deal with tools and management models that can be applied in the management processes of institutions.

The main limitation of this study is related to the periodical used to structure the collaborative network in the area. It is recommended for future studies to adopt more than one journal, as well as to expand the temporal cut of the research. In addition, when we carried out the search of research groups in the $\mathrm{DRG} / \mathrm{CNPq}$, it is recommended to include in the filters the term University Management as a keyword of the research line. In relation to the quantity of researchers from the research groups found in the DRG/CNPq in the collaborative network of the GUAL magazine, it is believed that it will be: the more expressive, the broader the time cut and the database searched.

\section{References}

Adams, J. (2012). The Rise of Research Networks. Nature, 490, 335-336.

https://www.nature.com/articles/490335a.pdf https://doi.org/10.1038/490335a

Campos, M. M., Guimarães, M. V. A. F., Ferreira, L. J. A., \& Alvares, L. M. A. R. (2017). Estudo da rede de colaboração científica em nanotecnologia na Empresa Brasileira de Pesquisa Agropecuária. TransInformação, 29, 115-123. 
http://repositorio.bc.ufg.br/xmlui/handle/ri/11919 https://doi.org/10.1590/2318-08892017000100011

Çavuşoğlu, A., \& Türker, I. (2014). Patterns of Collaboration in Four Scientific Disciplines of the Turkish Collaboration Network. Physica A: Mecânica Estatística e suas Aplicações, 413, 220-229.

https://www.sciencedirect.com/science/article/pii/S0378437114005500 https://doi.org/10.1016/j.physa.2014.06.069

Conselho Nacional de Desenvolvimento Científico E Tecnológico [CNPq]. (2018). Diretório dos Grupos de Pesquisa no Brasil: o que é.

http://lattes.cnpq.br/web/dgp/o-que-e/

Conselho Nacional de Desenvolvimento Científico E Tecnológico [CNPq]. (2016). Censoatual: Principaisresultados. http://lattes.cnpq.br/web/dgp/censo-atual/

Cruz, A. P. C., Espejo, M. M. S. B., Costa, F., \& Almeida, L. B. (2011). Perfil das redes de cooperação científica: Congresso USP de controladoria e contabilidade-2001 a 2009. Revista Contabilidade \& Finanças-USP, São Paulo, 22, 64-87.

http://www.redalyc.org/html/2571/257119478005/ https://doi.org/10.1590/S1519-70772011000100005

Domingos, M. (2004). A trajetória do CNPq. Acervo, Rio de Janeiro, 17, 19-40. http://revista.arquivonacional.gov.br/index.php/revistaacervo/article/view/159/159

Guimarães, R. (2002). Pesquisa no Brasil: a reforma tardia. São Paulo em Perspectiva, 16, 41-47.

http://www.scielo.br/scielo.php?script=sci_arttext\&pid=S0102-88392002000400008 https://doi.org/10.1590/S0102-88392002000400008

Jacamossi, S. E., \& Silva, M. Z. (2016). Influência da incerteza ambiental na utilizacão de sistemas de controle gerencial em uma instituicão de ensino superior. REGE-Revista de Gestão, 23, 75-85.

https://www.sciencedirect.com/science/article/pii/S180922761630008X https://doi.org/10.1016/j.rege.2015.10.003

Killcoyne, S., Carter, G. W., Smith, J., \& Boyle, J. (2009). Cytoscape: A Community-Based Framework for Network Modeling. Methods in Molecular Biology, 563, 219-239. https://www.ncbi.nlm.nih.gov/pubmed/19597788 https://doi.org/10.1007/978-1-60761-175-2_12

Leite, D., Caregnato, C. E., Lima, E. G. S., Pinho, I., Miorando, B. S., \& Silveira, P. B. (2014). Avaliação de redes de pesquisa e colaboração. Avaliação: Revista da Avaliação da Educação Superior, 19, 291-312.

http://www.redalyc.org/html/219130127014/ https://doi.org/10.1590/S1414-40772014000100014

Oliveira, J. J. (2016). Ciência, tecnologia e inovação no Brasil: Poder, política e burocracia na arena decisória. Revista de Sociologia e Política, 24, 129-147. http://www.scielo.br/pdf/rsocp/v24n59/0104-4478-rsocp-24-59-0129.pdf

Pucciarelli, F., \& Kaplan, A. (2016). Competition and Strategy in Higher Education: Managing Complexity and Uncertainty. Business Horizons, 59, 311-320. https://www.sciencedirect.com/science/article/pii/S0007681316000045 https://doi.org/10.1016/j.bushor.2016.01.003

Revista Gestão Universitária na América Latina [GUAL]. (2018). Sobre a revista. GUAL-Revista Gestão Universitária na América Latina, ISSN 1983-4535, Florianópolis, Santa Catarina, Brasil. https://www.periodicos.ufsc.br/index.php/gual/about

Rossoni, L., Hocayen-da-Silva, A. J., \& Ferreira Júnior, I. (2008). Estrutura de relacionamento entre instituições de pesquisa do campo de Ciência de Tecnologia no Brasil. 
RAE-Revista de Administração de Empresas, 48, 34-48.

http://bibliotecadigital.fgv.br/ojs/index.php/rae/article/view/36737

https://doi.org/10.1590/S0034-75902008000400004

Santana, G. A., Silva, F. M., Sobral, N. V., \& Ferreira, M. H. (2014). Indicadores dos grupos de pesquisa da área de Gestão da Informação na Região Nordeste: Um enfoque para a colaboração em artigos de periódicos. Em Questão, 20, 229-252. http://www.redalyc.org/html/4656/465645971014/

Santin, D. M., Vanz, S. A. S., \& Stumpf, I. R. C. (2016). Collaboration Networks in the Brazilian Scientific Output in Evolutionary Biology: 2000-2012. Anais da Academia Brasileira de Ciências, 88, 165-178.

http://www.scielo.br/scielo.php?pid=S0001-37652016000100165\&script=sci_arttext https://doi.org/10.1590/0001-3765201620140620

Severino, A. J. (2009). Pós-graduação e pesquisa: O processo de produção e de sistematização do conhecimento. Revista Diálogo Educacional, 9, 13-27.

https://periodicos.pucpr.br/index.php/dialogoeducacional/article/view/3640/3556 https://doi.org/10.7213/rde.v9i26.3640

Sidone, O. J. G., Haddad, E. A., \& Mena-Chalco, J. (2014). Padrões de colaboração científica no Brasil: O espaço importa. In Anais do XLI Encontro Nacional de Economia (pp. 1-34). São Paulo: ANPEC-Associação Nacional dos Centros de Pós-graduação em Economia. http://www.usp.br/nereus/wp-content/uploads/TD_Nereus_09_2013_v2.pdf

Silva, H. A. S., Reina, D. R. M., Ensslin, S. R., \& Reina, D. (2012). Programas de pós-graduação em contabilidade: Análise da produção científica e redes de colaboração. Revista de Contabilidade e Organizações, 6, 146-162.

http://www.redalyc.org/html/2352/235223852008/ https://doi.org/10.11606/rco.v6i14.45420

Smoot, M. E., Ono, K., Ruscheinski, J., Wang, P. L., \& Ideker, T. (2011). Cytoscape 2.8: Novos recursos para integração de e visualização de redes. Bioinformática, 27, 431-432. https://www.ncbi.nlm.nih.gov/pmc/articles/PMC3031041/

Soares, G. A. D., Souza, C. P. R., \& Moura, T. W. (2010). Colaboração na produção científica na ciência política e na sociologia brasileiras. Revista Sociedade e Estado, 25, 525-538. https://doi.org/10.1590/S0102-69922010000300006 http://www.scielo.br/scielo.php?script=sci_arttext\&pid=S0102-69922010000300006

Solla Price, D. J. (1976). O desenvolvimento da ciência: Análise histórica, filosófica, sociológica e econômica. Rio de Janeiro: Livros Técnicos e Científicos.

Solla Price, D. J., \& Beaver, D. (1966). Collaboration in an Invisible College. American Psychologist, 21, 1011-1018. https://doi.org/10.1037/h0024051

https://www.researchgate.net/profile/Donald_Beaver2/publication/17263883_Collabor ation_in_an_Invisible_College/links/54070ff80cf23d9765a8342e/Collaboration-in-an-I nvisible-College.pdf

Sutanto, E. M. (2017). The Influence of Organizational Learning Capability and Organizational Creativity on Organizational Innovation of Universities in East Java, Indonesia. Asia Pacific Management Review, 22, 128-135.

https://www.sciencedirect.com/science/article/pii/S1029313215201042 https://doi.org/10.1016/j.apmrv.2016.11.002

Valerio, P. M. (1994). Espelho da ciência: Avaliação do programa. Setorial de Publicações em Ciência e Tecnologia da FINEP (160 p). Rio de Janeiro: FINEP, IBICT.

Vanz, S. S. A., \& Stumpf, I. R. C. (2010). Colaboração científica: Revisão teórico conceitual. Perspectivas em Ciência da Informação, 15, 42-45. 
http://www.scielo.br/pdf/pci/v15n2/a04v15n2

https://doi.org/10.1590/S1413-99362010000200004

Wersun, A. (2017). Context and the Institutionalisation of PRME: The Case of the University for the Common Good. The International Journal of Management Education, 15, 249-262. https://www.sciencedirect.com/science/article/abs/pii/S1472811717301374 https://doi.org/10.1016/j.ijme.2017.02.012 